\title{
On the Classification of Subtitling
}

\author{
Dayan Liu \\ School of Foreign Languages, Chongqing Jiaotong University, No.66, Xuefu Road, Nan'an District, Chongqing, China
}

\begin{abstract}
Subtitling is one of the two most common modes of audiovisual translation. The starting point of research on subtitling might be its classification. As the types of subtitles in existence seem too varied to be accounted for, the classification of them risks being overlapping, intricate or meticulous, which would make a systematic study of the subject all the harder. In view of the pitfalls of classification, the principles of being simple, clear and inclusive in classifying subtitles are established. Guided by those principles and measured by the major linguistic and technical parameters, the existing types and new types of subtitles can be classified and grouped into corresponding categories, exhibiting distinctive characteristics and targeting different audiences. The classification proposed and the types of subtitles discussed in this paper will shed some light on how subtitling can be conducted in the future in the hope of assisting both academic research and professional practice.
\end{abstract}

Index Terms — subtitling, parameter, classification, audiovisual translation, fansubbing

\section{INTRODUCTION}

Up to now, research has not done justice to audiovisual translation as a whole, not to say subtitling, which has been largely ignored by translation studies. Some scholars refuse to acknowledge its status, as Fawcett (1996, p.69) once pointed out, "in view of the synchronization requirement some have even questioned whether it should be considered a type of translation at all". However, with the increasing recognition of audiovisual translation or screen translation as an important discipline within the scope of translation studies, research on subtitling has gained momentum.

There is no denying that subtitling is one of the two most common modes of audiovisual translation, with the other being dubbing. It is " $\mathrm{A}[\mathrm{a}]$ term used to refer to one of the two main methods of language transfer used in translating types of mass audio-visual communication such as film and television" (Shuttleworth \& Cowie, 2004, p.61). Varied as its conceptions are, it is generally agreed that subtitles are translated utterances, written translations or written target texts. Luyken et al. (1991, p.31), the earliest scholars engaged in the study of this field, understood subtitles as:

... condensed written translations of original dialogue which appear as lines of text, usually positioned towards the foot of the screen. Subtitles appear and disappear to coincide in time with the corresponding portion of the original dialogue and are almost always added to the screen image at a later date as a post-production activity.

This description outlines the most distinctive characteristics of subtitling in terms of the content (written translations), position (the foot of the screen), presentation (synchrony), production (post-production activity) and nature (additive).

Subtitling is used for some audiovisual products, such as cinema, television, video, DVD, LaserDisc, CDRom, computer games, Internet and live performances, etc. It enjoys some advantages over dubbing, as "an inexpensive, quick, foreign-culture friendly and generally fairly politically correct mode of screen translation" (O'Connell, 2007, p.67). Subtitling poses new challenges to traditional translation, like the space and time constraints inherent in the subtitling process, the visual conventions, the shift of modes from speech to writing as well as other challenges that have been brought along. One of them is its classification, which might be the starting point of any scholarly work on this subject. It is no easy task. The difficulty lies not only in the multitude of the types in existence, but also in the fact that it has a lot to do not with language alone but with technology, etc. Anyway, a proper and easily accessible classification will sure help both the scholarly study of subtitling and its professional practice.

\section{GUIDING PRINCIPLES OF ClassifiCATION}

Prior to the discussion of the types of subtitles as classified by the author, mention should be made of some other approaches in an attempt to shed some light on the guiding principles of classification to be presented here. To this end, two approaches, namely one of the earliest and one of the latest classifications, are chosen as cases in point since both display some flaws to be guarded against in this paper.

Jan Ivarsson (1992), a much cited authority on subtitling, once proposed a classification, in which linguistic and technical parameters, as well as other parameters, like areas of application, audience, writing skills and time, are present. By those parameters, he distinguished six types: subtitling for cinema and television, multilingual subtitling, teletext subtitling, reduced subtitling, subtitling live or in real time, the translation of opera, theatrical works, conferences, etc. For easy reading, Ivarsson's categories are explained in table 1 drafted by the author, with each type having its own focal point (marked by “+”) (Bartoll, 2004). 
TABLE 1

JAN IVARSSON'S CLASSIFICATION OF SUBTITLES (1992)

\begin{tabular}{|c|c|c|c|c|c|c|}
\hline types parameters & $\begin{array}{l}\text { areas of } \\
\text { application }\end{array}$ & languages & technology & audience & $\begin{array}{l}\text { writing } \\
\text { skills }\end{array}$ & time \\
\hline $\begin{array}{l}\text { subtitling for cinema and } \\
\text { television }\end{array}$ & + & & & & & \\
\hline multilingual subtitling & & + & & & & \\
\hline teletext subtitling & & & $\begin{array}{l}+ \\
\text { used on } \\
\text { television } \\
\end{array}$ & $\begin{array}{l}\text { the hard of } \\
\text { hearing }\end{array}$ & & \\
\hline reduced subtitling & $\begin{array}{l}\text { news or live } \\
\text { events, such as } \\
\text { sports } \\
\text { broadcasts }\end{array}$ & & $\begin{array}{l}\text { similar to } \\
\text { teletext }\end{array}$ & & $\begin{array}{l}+ \\
\text { reduction }\end{array}$ & \\
\hline $\begin{array}{l}\text { subtitling live or in real } \\
\text { time }\end{array}$ & $\begin{array}{l}\text { basically the } \\
\text { same as } \\
\text { reduced } \\
\text { subtitling }\end{array}$ & & $\begin{array}{l}\text { using a special } \\
\text { apparatus that } \\
\text { allows for faster } \\
\text { writing }\end{array}$ & & $\begin{array}{l}\text { faster } \\
\text { writing }\end{array}$ & + \\
\hline $\begin{array}{l}\text { the translation of opera, } \\
\text { theatrical works, } \\
\text { conferences, etc. }\end{array}$ & + & & $\begin{array}{l}\text { using a special } \\
\text { screen to } \\
\text { display the } \\
\text { titles }\end{array}$ & & & \\
\hline
\end{tabular}

While Ivarsson's categories seem intricate and exact careful sorting, Eduard Bartoll distinguishes his types based on more meticulous parameters. Eduard Bartoll (2004, pp.55-57) lists as many as nine parameters, including placing, the filing of subtitles, localization, mobility, optionality, time, audiovisual product to be subtitled, channel/means of broadcast and colour. His types are demonstrated in table 2:

TABLE 2

EDUARD BARTOLL'S CLASSIFICATION OF SUBTITLES (2004)

\begin{tabular}{|l|l|}
\hline Parameters & Types of subtitles \\
\hline placing & centred and non-centred subtitles \\
\hline the filing of subtitles & inseparable and separable part, like electronic subtitles \\
\hline localization & subtitles, intertitles and surtitles \\
\hline mobility & mobile and fixed subtitles \\
\hline optionality & optional or closed subtitles and non-optional or open subtitles \\
\hline time & pre-recorded and simultaneous subtitles \\
\hline $\begin{array}{l}\text { audiovisual product to be } \\
\text { subtitled }\end{array}$ & $\begin{array}{l}\text { cinema, television, video, DVD, LaserDisc, CDRom, computer games, Internet (Streaming } \\
\text { Video), and live performances }\end{array}$ \\
\hline channel/means of broadcast & $\begin{array}{l}\text { through an impression upon the audiovisual product itself, by teletext, on a display, e.g. } \\
\text { electronic, projected on top of the product or on a nearby screen or by simultaneous broadcasting }\end{array}$ \\
\hline colour & $\begin{array}{l}\text { depending on the interlocutors; the colour of the film, whether in black and white or colour; and } \\
\text { the products to be subtitled }\end{array}$ \\
\hline
\end{tabular}

Both approaches exhibit the same drawback, that is to say, both try to be exhaustive but in the end turn out to be too overlapping or meticulous to be applicable. Just think about the types as varied as people's thumbprints which would render them almost unclassifiable and unaccountable. Such classifications, though they encompass almost all the types in existence in the corresponding periods, would leave most of us even more confused, thus fail the purpose of classification. It is revealed that a very sophisticated and intricate classification can go nowhere but make a systematic study of the subject all the harder. In light of the perception, it is desirable that a classification should fulfill two conditions though it is often quite hard to achieve: first, it needs to be as simple and clear as possible in order to provide guidance for academic research; second it needs to be inclusive enough, highlighting the most distinctive features, to cover the existing types. Those are the guiding principles of classification to be adopted here. Under the principles, two distinctions can be made, the traditional classification and the new classification, within each of which some major types of subtitles are outlined, based on different parameters.

\section{TRADITIONAL ClassiFICATION}

Traditionally, there are two ways of classifying subtitles, based on two different parameters, linguistic and technical, despite the existence of other less frequently used parameters.

\section{A. Linguistic Parameter}

Speaking of the linguistic parameter, one immediately thinks of language, as it is the most distinctive feature in this group, which will become the starting point of traditional classification. The parameter of language, as Bartoll (2004, p.57) puts it, signifies "the relationship that is established between source and target languages, whether this is the same or not." In line with his understanding, there are interlingual and intralingual subtitles or subtitling (Gottlieb, 1997, 2005; Shuttleworth \& Cowie, 2004; Bartoll, 2004). With a slight difference in wording, Díaz Cintas (2001) also names two, intralinguistic subtitles and interlinguistic subtitles, in addition to a number of other types. 


\section{Interlingual subtitling}

Interlingual subtitling, according to Gottlieb (1997), literally is the subtitling between two languages. It is a "transfer from a source language (SL) to a TL ....", designating the relationship between different source and target languages (Díaz Cintas, 2006, p.199). Or to use an alternative term, interlinguistic subtitles, which occur "where there is translation" (Bartoll, 2004, p.57). This type is similar to multilingual subtitling in Ivarsson's categories. The essence of this type is that there must be a transfer or translation between two different languages, though it refers to subtitling instead of traditional written translation. It should be noticed that in this group not only two languages are involved but also two dimensions, speech and writing. Therefore, this type is alternatively called "diagonal subtitling" or "oblique subtitling" by Gottlieb (1997, pp.71-72), meaning that both mode and language are changed, crossing over from speech in one language to writing in another language.

\section{Intralingual subtitling}

According to Gottlieb's (1997) classification, intralingual subtitling is the subtitling within the same language. It concerns the relationship between the same source and target languages. Alternatively, it is called intralinguistic, and since it works between the same languages, intralinguistic subtitles occur "where there is transcription" (Bartoll, 2004, p.57). Díaz Cintas (2006, p.199) echoes this view and affirms no change of language, thus he calls it "captioning". Like interlingual subtitling, it touches upon dimensions as well. Gottlieb (2005, p.247) dubs it "vertical" subtitling, which means that only mode is changed, but not language, taking speech down in writing in the original language. This type is mainly targeted at the following groups of people: the deaf and hard of hearing, language learners and karaoke singers (Díaz Cintas, 2001, 2006; Gottlieb, 2005; O’Connell, 2007). The first two groups are explained specifically.

\section{(1) The deaf and hard of hearing}

Surprisingly in such countries as the UK and the US, the concept of subtitling is generally equated with intralingual (English into English) subtitling for the deaf and hard-of-hearing (SDH) (Díaz Cintas \& Anderman, 2009). But in other countries, intralingual subtitling needs to be specified in this regard. For those deaf and hard of hearing, this process involves not only turning the actors' dialogues into written speech, but also keeping all the paratextual information vital for plot development and scene-setting, which is inaccessible to deaf people if merely from the soundtrack, like telephones ringing, knocks on the door, etc. (Díaz Cintas, 2006). This type of subtitling is gaining power nowadays, thanks to the efforts of pressure groups in promoting the interests of those with hearing problems. Some television channels, such as the BBC, are committed to broadcasting a high percentage of their programmes with intralingual subtitles. The BBC, for instance, vows to raise the present percentage of programmes/hours of $66 \%$ that are subtitled for the hard of hearing to $80 \%$ by 2004 and 100\% soon afterwards (Díaz Cintas, 2006, p.203).

\section{(2) Language learners}

Language learners constitute another group targeted by intralingual subtitling. This group encompasses foreign students along with other minorities such as immigrants, refugees, or those with literacy problems, who intend to improve their language skills by watching television programmes and making use of their audio and visual input (Vanderplank, 1988). An example of bi-modal L2 input is the situation in which English speakers viewing a Russian language film with Russian subtitles. For the same purpose, bilingual subtitles, as categorized by Díaz Cintas (2001), are used as well. The use of subtitles in language learning, in particular, second language acquisition, is a subject of much value to teachers and scholars, and therefore merits further research.

\section{(3) dialects}

As for those suited for intralingual subtitling, one group often goes unnoticed — the audience having problems with dialects. Subtitling dialects, which is quite common now, should be added to the list.

Intralingual subtitling is chiefly used for television, including some domestic and foreign-language programmes for different groups with different purposes. It is, according to de Linde (1999), non-existent in cinema. But in reality, the use of intralingual subtitling can be found in cinema when, for instance, the actors on screen, as conditioned by the roles they are playing, speak with accents which are difficult for certain audience to understand even though they share the same language. A case in point is the British film Trainspotting (Danny Boyle, 1996) which was released with subtitles in the United States, for the actors speak English with a strong Scottish accent which is difficult for the US audience generally (Díaz Cintas, 2006). In some cases, dialects are required to be translated for the sake of the rest of countrymen, which often occurs in Flanders (Remael et al., 2008).

The same practice can be found in Italy where since the early 1990s a group of filmmakers from the south of the country have needed their local dialect, the predominant language in their films, subtitled. Abele Longo delved into this subject. In the essay Subtitling the Italian south, Longo used two films by Ciprì and Maresco's Totò che visse due volte, set in Palermo, and Piva's LaCapaGira, set in Bari, to discuss the diegetic value of the intralingual subtitles needed in the original version and came with some impressive findings (Díaz Cintas, 2009).

Intralingual subtitling is practiced in China, a country with more than 50 ethnic groups who speak their own dialects. Even within the Han Group, dialects still vary though they share the same language. In China, intralingual subtitles are used both on TV and in cinema. The domestic TV programmes broadcast with mandarin subtitles help foster audience's comprehension of the content and popularize mandarin. In Chinese cinema, when some dialects are used in the domestic films, or the actors speak with accents, the films are usually subtitled with mandarin.

\section{Other linguistic parameters}


From the linguistic perspective, mention should be made of Luyken's classification (1991), in which he divides subtitling into traditional subtitling and simultaneous subtitling, the former including subtitling in complete sentences, reduced sentences and bilingual sentences. It seems that he regards sentences as the yardstick against which to measure some types of subtitling.

The linguistic parameter is not only limited to language, but is "complemented by the purpose the subtitles have for the transmitter" (Bartoll, 2004, p.57). By this parameter, subtitles are distinguished between instrumental subtitles and documentary subtitles, following Christiane Nord's terminology (1995). Instrumental subtitles are subtitles in an attempt to communicate in the target language. They involve both translation and transcription (fundamentally reduced) of an oral text and target people who either do not understand it in another language or because they cannot hear it due to hearing impairment. Documentary subtitles, on the other hand, encompass only transcription (fundamentally complete), and are meant for people with different purposes, for learning languages or singing karaoke, etc. (Bartoll, 2004)

\section{B. Technical Parameter}

Besides linguistic parameter, technical parameter is another important yardstick of classifying subtitles. From a technical perspective, there is usually a dichotomy between open subtitles and closed subtitles (Gottlieb, 1997, 2005; Díaz Cintas, 2001; Shuttleworth \& Cowie, 2004; Bartoll, 2004; O’Connell, 2007). Bartoll (2004) uses the parameter of optionality (see Table 2) to distinguish the two, open subtitles are non-optional, which means that the viewer cannot decide if he wants the subtitles to appear on the screen, for the subtitles are always present, while closed subtitles are known as optional subtitles, as the viewer can decide if he wants the subtitles to appear on the screen.

\section{Open subtitles}

Open subtitles are subtitles that constitute part of the original film or broadcast and cannot be removed from the screen (Gottlieb, 1997, 2005; Shuttleworth \& Cowie, 2004; O'Connell, 2007). They are also called burnt-on subtitles because they were once etched on to the film celluloid using acid, but this is replaced by laser technology now (O’Connell, 2007).

This type is most often used in three areas: cinema, television, and sometimes videos. Gottlieb (1997) maintains that all film subtitling belongs within this category. Open subtitles are used to carry interlingual translation for foreign language films shown in cinemas. Technically, they are either a physical part of the film as in films for public viewing or transmitted separately as at festival screenings. Similarly, they are used for television programmes with the original soundtrack, often transmitted terrestrially and broadcast as part of the television picture. As for videos, open interlingual subtitles, as a much cheaper option than dubbing, are used on many foreign language videos.

\section{Closed subtitles}

Closed subtitles, known as "captions" in the US (O'Connell, 2007, p.133), first occurred on television in the 1970s with the development of technology, such as Teletext technology, cable or satellite channels (Bartoll, 2004, O'Connell, 2007, Gottlieb, 2005). They are usually encoded in the transmission signal, broadcast separately, and then selected by those viewers on a remote-control unit with a teletext television set and a decoder. In addition to television, they are found in DVD, on the Internet (Streaming Video) and in LaserDisc.

The targeted audience includes the deaf and hard of hearing, who need to be assisted by subtitles, mainly intralingual subtitles, with longer exposure time and explanatory information such as 'The clock ticks' to supplement the sound. It is also possible to encode them on videos, due to the efforts of the National Captioning Institute (NCI) in the United States on behalf of the deaf viewers. Closed subtitles are also aimed at different speech communities. Sometimes, the closed interlingual television subtitles are transmitted by satellite, offering different speech communities different versions of the same programme simultaneously.

\section{Other technical parameters}

This dichotomy between open and closed subtitles does not rule out the possibility of other technology-related types, for instance, in Jan Ivarsson's categories (see Table 1), there are teletext subtitling, subtitling live or in real time, subtitling for opera, theatrical works, conferences, etc., which employ special technologies. The parameters arrayed by Bartoll also have a lot to do with technology, like the following (see Table 2): 1) audiovisual products to be subtitled; 2) channel/means of broadcast; 3) the filing of subtitles, etc. Bartoll also listed another technology-related type, the so-called electronic subtitles which are projected through luminous panels. By those parameters, some more types of subtitles can be distinguished.

The above-mentioned categories, either from a linguistic or technical perspective, can be grouped under the heading of traditional subtitling. But note should be taken of Díaz Cintas's categories of subtitling (2001), in which he juxtaposes traditional subtitling and simultaneous subtitling, along with intralinguistic, interlinguistic and bilingual subtitles, open and closed subtitles.

\section{NEW TyPes OF SubTitLes}

No other types of translation have such a close tie with technological development than audiovisual translation. Subtitling that falls into this domain goes hand in hand with new technical advances, and accordingly new types of subtitles emerge, which have not been sufficiently accounted for by those pioneers in this area of studies. The 
parameters to be capitalized on are still along the lines discussed previously or the combination of them, as those parameters are general enough to embrace the existing forms of subtitles, and simultaneously remain open to other types yet to come. This way the classification can stay straightforward and easily understandable. Two major new developments worth mentioning, either linguistically or technically, are interlingual subtitling for the deaf and hard of hearing and amateur subtitling.

\section{Interlingual subtitling for the deaf and hard of hearing (SDH)}

Along the linguistic line, the new type that has emerged recently is the interlingual subtitling for the deaf and hard of hearing $(\mathrm{SDH})$. The type of subtitling most often designated for the hearing impaired is intralingual subtitling. But this brings to the fore the question if those people with hearing problems only watch programmes in their mother tongue and never in a different language. Common sense tells us that the possibility of the latter cannot be ruled out.

With the assumption that standard interlingual subtitles can provide enough information for all, this type has not been adequately accounted for in many countries. For instance, in Portugal, Greece and the Scandinavian countries, interlingual subtitling for the deaf and hard-of-hearing is "rarely seen as a specific kind of subtitling" (Díaz Cintas \& Anderman, 2009, p.13). But the awareness is being heightened that interlingual subtitling for the deaf and hard of hearing differs from that for the ordinary viewers with no hearing problems, for the standard interlingual subtitles don't cater for this special group of audience and turn out to be inappropriate for their needs. Josélia Neves, who takes special interest in this subject, points out that the standard interlingual subtitles have two drawbacks: either they offer more information than those deaf viewers can digest, or they need to add more for the adequate transference of the whole semiotic message (Díaz Cintas \& Anderman, 2009). In a word, the needs of this special group should be adequately dealt with in order to gain true access to audiovisual material.

This type is made technically possible by the advent of digital television and DVDs in particular. The film Thelma \& Louise (Ridley Scott, 1991), for instance, can be bought on DVD with two sets of subtitled in German incorporated, one for ordinary viewers and the other for the hearing impaired (Díaz Cintas, 2006). Those technologies enable the deaf viewers to watch programmes in a number of languages usually unavailable in cinema. Despite the fact that some DVDs now do carry the option of interlingual SDH, it is by no means a common practice in most countries.

\section{Amateur subtitling}

As the nature of AVT foreshadows its close link with the latest technical developments, the emergence of new audiovisual products, like Internet, videogames or DVDs and the new computer-based techniques, necessitates new subtitling possibilities. Thanks to the ubiquity of the Internet and the use of freeware computer programs, another new type is made possible, namely amateur subtitling. What falls into this category includes fansubbing. It is said that fansubs came into existence in the late 1980s (Bogucki, 2009, p.49). Fansubs are originally subtitles "of various Japanese anime productions made unofficially by fans for non-Japanese viewers" (ibid.). But now this activity goes well beyond those Japanese anime productions to cover any foreign film or program, as the following describes:

A fansub (short for fan-subtitled) is a version of a foreign film or foreign television program which has been translated by fans (as opposed to an officially licensed translation done by professionals) and subtitled into a language other than that of the original. (http://en.wikipedia.org/wiki/Fansub)

The practice of making fansubs is called fansubbing and it is done by a fansubber. Fansubs can simply be understood as subtitles "by fans for fans" (Díaz Cintas, 2009, p.11). This type of subtitling is more creative and idiosyncratic than traditional subtitling, and it is not directed toward the market but the free distribution of audiovisual programmes over the Internet. In Lukasz Bogucki's words, the main purpose of fansubbing is:

... to make a contribution in an area of particular interest and to popularise it in other countries, making it accessible to a broader range of viewers/readers, who belong to different linguistic communities (Bogucki, 2009, p.49).

Fansubbing usually follows a series of procedures. First, a copy of the original material, which is an unaltered native language source (called a "raw"), needs to be obtained, ideally from the highest quality source material available. Second, the script is subtitled and synced to the media. There are two types of fansubs, hard and soft subtitles. Hard subtitles are encoded into the source material while soft subtitles are mixed to the video from another data file, enabling the display of subtitles to be switched by the viewer, or the data file to be altered. (http://en.wikipedia.org/wiki/Fansub) Digital subtitling programmes are used in fansubbing. Many of such programmes are available online, such as Subtitle Workshop, Media Subtitler, Virtual Dub and Aegisub, which have become a common occurrence in the practice (Díaz Cintas, 2009).

With its being a fairly new phenomenon, the academic research on fansubbing is scarce. One notable contribution is made by Bogucki in his Amateur Subtitling on the Internet. He does not survey the global situation in this regard, but only takes a look at Polish subtitles, with one film The Fellowship of the Ring in mind, in an effort to investigate the criteria for quality assessment and their application to audiovisual translation (Díaz Cintas \& Anderman, 2009). In Bogucki's findings, he notices a big disadvantage of amateur subtitling: "a multitude of mistakes and misinterpretations" are likely to occur, due to the low-quality of the recording and the poor grasp of the original dialogue (the Source Text) by the subtitler. (Díaz Cintas \& Anderman, 2009, p.10)

Ever since its existence, amateur subtitling has had some legal and ethical issues that still remain to be resolved today. Not only is its status open to discussion, but also its characteristics, for instance, whether the traditional subtitling conventions and strategies still remain useful in this new form. It is argued that the constraints governing professional 
subtitling and amateur subtitling are dramatically different. Some interesting impacts of this new type on other types of subtitling can be highlighted, like the use of the translator's notes on the screen, which is sometimes applied in some commercialized films and audiovisual programmes (Díaz Cintas, 2009). With the hurdles in amateur subtitling overcome, this new form is sure to flourish in the audiovisual field.

\section{CONCLUSION}

The types of subtitles discussed here are designed for different programmes, audiences or purposes. Some scholars propose the production of different subtitles for the same programme. Neves, for instance, advocates the provision of multiple solutions for each audiovisual programme, like dubbing, interlingual subtitles, intralingual and interlingual SDH, adapted subtitling, so that those subtitles can best suit the specific needs of different audiences (Díaz Cintas \& Anderman, 2009). Whether it is practically possible is still being hotly debated, but it will shine a light on how subtitling can be conducted in the future.

Subtitling, or audiovisual translation in general, exhibits the great potential for new progress. Those different types, with new developments and innovations under way, promise to challenge, if not threaten, the future of audiovisual translation modes and conventions, bringing in new insights and inspirations. With the evolution of AVT, keeping abreast of all the latest developments in technology, in particular, the interaction of different media, subtitling, together with other modes of AVT, merits further scholarly attention and professional innovation, in the hope of assisting both scholars and translators in their respective areas of work.

NOTE:

The films mentioned in this paper:

1. Trainspotting, a 1996 British black comedy/drama film directed by Danny Boyle based on the novel of the same name by Irvine Welsh and starring Ewan McGregor, Ewen Bremner, Jonny Lee Miller, Kevin McKidd, Robert Carlyle, and Kelly Macdonald.

2. Totò che visse due volte, a 1997 Italian film directed by Daniele Ciprì and Franco Maresco, a film with 3 episodes set in Palermo, a port on the north coast, the capital of Sicily, starring Salvatore Gattuso.

3. LaCapaGira, a 2000 Italian film directed by Alessandro Piva, set in Bari, an industrial seaport on the Adriatic coast of southeast Italy.

4. Thelma \& Louise, a 1991 adventure female buddy film directed by Ridley Scott and written by Callie Khouri. It stars Geena Davis as Thelma and Susan Sarandon as Louise.

5. The Fellowship of the Ring, a 2001 epic fantasy film directed by Peter Jackson based on the first volume of J. R. R. Tolkien's The Lord of the Rings (1954-1955). It is the first installment in the series, followed by The Two Towers (2002) and The Return of the King (2003).

\section{REFERENCES}

[1] Bartoll, Eduard. (2004). Parameters for the classification of subtitles. In Pilar Orero (ed.), Topics in Audiovisual Translation (pp.53-60). Amsterdam/Philadelphia: John Benjamins Publishing Company.

[2] Bogucki, Łukasz. (2009). Amateur Subtitling on the Internet. In Jorge Díaz Cintas and Gunilla Anderman (eds.), Audiovisual Translation: Language Transfer on Screen (pp.49-57). Basingstoke: Palgrave Macmillan.

[3] de Linde, Z. and N. Kay. (1999). The semiotics of Subtitling. Manchester: St. Jerome.

[4] Díaz Cintas, Jorge. (2001). La traducción audiovisual: el subtitulado. Salamanca: Almar.

[5] Díaz Cintas, Jorge. (2006). Audiovisual translation in the Third Millennium. In G. Anderman \& M. Rogers (eds.), Translation Today: Trends and Perspectives (pp.192-204). Beijing: Foreign Language Teaching and Research Press.

[6] Díaz Cintas, Jorge. (2009). Introduction - Audiovisual Translation: An Overview of its Potential. In Jorge Díaz Cintas (ed.), New Trends in Audiovisual Translation (pp.1-18). Bristol: Multilingual Matters.

[7] Díaz Cintas, Jorge and Gunilla Anderman. (2009). Introduction. In Jorge Díaz Cintas and Gunilla Anderman (eds.), Audiovisual Translation: Language Transfer on Screen (pp.1-17). Basingstoke: Palgrave Macmillan.

[8] Fawcett, Peter. (1996). Translating Film. In Geoffrey T. Harris (ed.), On Translating French Literature and Film (pp.65-88). Amsterdam: Rodopi.

[9] Gottlieb, Henrik. (1997). Subtitles, Translation \& Idioms. Thesis. Copenhagen: University of Copenhagen.

[10] Gottlieb, Henrik. (2005). Subtitling. In Mona Baker (ed.), Routledge Encyclopedia of Translation Studies (pp.244-248). Shanghai: Shangahai Foreign Language Education Press.

[11] Ivarsson, J. (1992). Subtitling for the media: A Handbook of an Art. Stockholm: Transedit.

[12] Luyken, Georg-Michael, Thomas Herbst, Jo Langham-Brown, Helene Reid and Hermans Spinhof. (1991). Overcoming Language Barriers in Television. Manchester: The European Institute for the Media.

[13] Nord, C. (1995). Textanalyse und Übersetzen. Heidelberg: Julius Groos.

[14] O'Connell, Eithne. (2007). Choices and Constraints in Screen Translation. In L. Bowker et. al.(eds.), Unity in Diversity? Current Trends in Translation Studies (pp.65-75). Beijing: Foreign Language Teaching and Research Press.

[15] Remael, A., De Houwer, A. and Vandekerckhove, R. (2008). Intralingual open subtitling in Flanders: Audiovisual translation, linguistic variation and audience needs. The Journal of Specialised Translation (10, 76-105). On WWW at http://www.jostrans.org/issue10/art_houwer.pdf: accessed 2014-1-19 22:00.

[16] Shuttleworth, Mark \& Moira Cowie. (2004). Dictionary of Translation Studies. Shanghai: Shanghai Foreign Language Education Press. 
[17] Vanderplank, R. (1988). The value of teletext sub-titles in language learning. ELT Journal 42, (pp.272-281).

[18] http://en.wikipedia.org/wiki/Fansub: accessed 2014-1-21 16:30.

Dayan Liu earned her MA in Translation Theory and Practice from Sichuan International Studies University, China, in 2000. She is currently an associate professor at the School of Foreign Languages, Chongqing Jiaotong University, Chongqing, China. Her research interests cover Translation Studies, intercultural communication, Teaching English to Speakers of Other Languages, Second Language Acquisition, teacher training and education, etc. 